\title{
Possible lethal enhancement of toxins from putative periodontopathogens by nicotine: implications for periodontal disease
}

\author{
N M Sayers, B P F A Gomes, D B Drucker, A S Blinkhorn
}

\begin{abstract}
Aim-To test the hypothesis that lethal synergy in the chick embryo model may occur between nicotine and bacterial products (cell-free extracellular toxins and cell lysates) of five putative periodontopathogens.

Methods-The lethality of cell-free extracellular toxins and cell lysates of five periodontal species was assessed with or without nicotine in the chick embryo assay system. Ten putative periodontopathogens (five species) were studied: Prevotella intermedia $(n=5)$, Porphyromonas gingivalis $(\mathrm{n}=1)$, Porphyromonas asaccharolytica (n = 1), Fusobacterium nucleatum $(\mathrm{n}=2)$, and Fusobacterium necrophorum $(\mathrm{n}=1)$.

Results-Simultaneous testing of cell-free extracellular toxins from isolates W50, PS2, PS3, PS4, and PS5 and nicotine resulted in a percentage kill significantly greater than expected (Fisher's Exact test). Simultaneous testing of cell lysates from isolates W50, PS2, and PS5 and nicotine resulted in a percentage kill significantly greater than expected (Fisher's Exact test).

Conclusions-Lethal synergy in the chick embryo model may occur between nicotine and toxins from putative periodontopathogens (both cell-free extracellular toxins and cell lysates). This may be an important mechanism by which smoking increases the severity of periodontal disease.

(f Clin Pathol 1997;50:245-249)
\end{abstract}

Turner Dental School, University of

Manchester

N M Sayers

B P F A Gomes

D B Drucker

A S Blinkhorn

School of Biological

Sciences, University of

Manchester

D B Drucker

Correspondence to:

Dr D B Drucker

Microbiology Laboratory,

Turner Dental School,

University of Manchester,

Higher Cambridge Street,

Manchester M15 6FH.

Accepted for publication 12 August 1996
Keywords: periodontopathogens; toxins; nicotine.

Smoking is a recognised independent risk factor for a number of diseases, including sudden infant death syndrome (SIDS). ${ }^{1}$ The association between smoking and oral health problems, such as chronic and rapidly progressive periodontal disease and acute necrotising ulcerative gingivitis, has been confirmed in many studies. ${ }^{2-6}$ Smoking has also been linked to the severity of certain aspects of periodontal disease, including probing depth, alveolar bone loss, tooth mobility, and tooth loss. ${ }^{7-9}$ However, smoking has not been shown to affect the range of microflora in diseased or healthy periodontal tissue. $^{710}$ Recognised putative periodontopathogens include Porphyromonas gingivalis, Fusobacterium nucleatum, Actinobacillus actino- mycetemcomitans, Prevotella intermedia, and Eikenella corrodens. ${ }^{5781011}$

Risk factors are factors that are epidemiologically associated with an increased likelihood of periodontitis occurring. They are not the same as causal agents; they can correlate with a causal agent without playing a distinct role in disease aetiology. ${ }^{8}$ Nevertheless, the known toxicity of nicotine and other smoking products suggests that a direct role might be possible in periodontal disease. ${ }^{12}$ Also certain bacterial species found in the oral cavity, such as Actinobacillus actinomycetemcomitans, have been positively associated with progressive periodontal disease. ${ }^{13}$ The latter may occur via the exogenous production of toxins and enzymes or by the release of toxins, such as endotoxin from all Gram negative species, upon cell lysis. Synergy between bacterial species may also occur. For example, certain Gram positive " $\beta$ haemolytic species" promote the growth of Prevotella intermedia and Porphyromonas gingivalis. ${ }^{8}$

Previous studies by some of the authors (NMS, DBD) using bacteria isolated from SIDS victims, showed that synergy between extracellular toxins of Gram negative and Gram positive bacteria, resulted in an increase in toxin virulence by up to $1011 \% .{ }^{14}$ Additionally, extracellular toxins from Gram positive staphylococci may also interact synergistically with endotoxin from Escherichia coli. ${ }^{15}$ Such enhancement of the virulence of extracellular toxins from both Gram positive and Gram negative bacteria may also be induced by nicotine. ${ }^{16}$

It is not known whether such potentiation of toxins by nicotine occurs with bacteria associated with progressive periodontal disease. Thus, the aim of the present study was to test the hypothesis that the potency of cell-free extracellular toxins and cell lysates of putative periodontopathogens may be enhanced by nicotine.

\section{Methods}

STRAINS TESTED

The identity and origin of the 10 bacterial isolates used in this study are given in table 1 . The identity of all strains was confirmed using the Rapid ANA II System (Innovative Diagnostic Systems Inc, Atlanta, Georgia, USA), according to the manufacturer's instructions.

GROWTH OF ORGANISMS

Our published methods were followed in which bacteria were inoculated as a lawn of growth 
Table 1 Source and identity of periodontal isolates

\begin{tabular}{|c|c|c|}
\hline Species & Strain & Source \\
\hline Prevotella intermedia & $\begin{array}{l}\text { MH3†, MH6†, MH15† } \\
\text { ATCC } 25261 \dagger \\
\text { PS1* }\end{array}$ & $\begin{array}{l}\text { Dr D A Devine } \\
\text { Dr R Gmür } \\
\text { Dr B P F A Gomes }\end{array}$ \\
\hline Porphyromonas gingivalis & W50† & Dr Aduse-Opoku \\
\hline Porphyromonas asaccharolytica & $\mathrm{PS} 2^{\star}$ & A Tavana $^{\mathrm{e}}$ \\
\hline Fusobacterium nucleatum & PS3^, PS4* & F Sadek ${ }^{f}$ \\
\hline Fusobacterium necrophorum & PS5* & A Tavana ${ }^{e}$ \\
\hline
\end{tabular}

${ }^{2}$ Dr D A Devine, Department of Biomedical Sciences, University of Bradford, West Yorkshire, UK. 'Dr R Gmür, Department of Oral Microbiology and General Immunology, Dental Institute, University of Zurich, Zurich, Switzerland.

'Dr B P F A Gomes, Department of Oral Medicine and Surgery, Turner Dental School, University of Manchester, Manchester, UK.

${ }^{d}$ Dr Aduse-Opoku, Department of Oral Microbiology, London Hospital Medical College, London, UK.

'A Tavana, School of Biological Sciences, University of Manchester, Manchester, UK.

${ }^{f} \mathrm{~F}$ Sadek, School of Biological Sciences, University of Manchester, Manchester, UK.

^Isolated clinically from periodontal tissue of patients attending the University Dental Hospital of Manchester.

†Culture collection strains.

onto a dialysis membrane overlaying culture plates. ${ }^{17}$ Briefly, test organisms were subcultured onto pre-reduced $5 \%$ horse blood fastidious anaerobe agar (FAA) plates and incubated anaerobically at $37^{\circ} \mathrm{C}$ for two days. Anaerobic conditions were achieved using a Model compact $M$ anaerobic workstation (Don Whitley Scientific, Bradford, UK), with an atmosphere of $5-10 \% \mathrm{H}_{2}, 10 \% \mathrm{CO}_{2}$ and $80-85 \% \mathrm{~N}_{2} \cdot{ }^{18}$ Bacterial suspensions of each isolate, equivalent to a McFarland Standard of 6, were prepared using $1 \mathrm{ml}$ Hank's balanced salt solution (HBSS). Aliquots $(100 \mu \mathrm{l})$ of each bacterial suspension were spread onto prereduced 5\% horse blood FAA plates. Each plate had been overlain previously with sterile dialysis membrane (Medicell International Ltd, London, UK.) size 13-2" (molecular weight cut-off $11 \mathrm{kDa}$ ). The plates were then incubated for two days at $37^{\circ} \mathrm{C}$ under anaerobic conditions (vide supra).

TOXIN PREPARATION

After growth supra-membranous material, which consisted of bacterial cells plus extracellular products greater than $11 \mathrm{kDa}$, was recovered using HBSS. The concentration of each bacterial suspension was assessed using a previously published method. ${ }^{17}$ Briefly, the absorbance (A) of dilutions ( 1 in 25 and 1 in 50 ) in phosphate buffered saline (PBS) for each bacterial suspension was assessed. This was achieved using a double-beam spectrophotometer (Pye-Unicam, Cambridge, UK) set at

Table 2 Concentration of cell-free extracellular toxins and cell lysates of periodontal isolates used in synergy experiments

\begin{tabular}{|c|c|c|c|c|c|}
\hline \multirow[b]{2}{*}{ Species } & \multirow[b]{2}{*}{ Strain } & \multicolumn{2}{|c|}{$\begin{array}{l}\text { Cell-free extracellular } \\
\text { toxins }\end{array}$} & \multicolumn{2}{|c|}{ Cell lysates } \\
\hline & & Dilution & $\%$ Killed & Dilution & $\%$ Killed \\
\hline${ }^{a} P$ intermedia & MH3 & Neat & 0 & 1 in 2 & 0 \\
\hline${ }^{a} P$ intermedia & MH6 & 1 in 4 & 0 & 1 in 4 & 0 \\
\hline${ }^{a} P$ intermedia & ATCC 25261 & Neat & 0 & 1 in 2 & 0 \\
\hline${ }^{2} P$ intermedia & MH15 & 1 in 2 & 0 & 1 in 4 & 0 \\
\hline${ }^{\mathrm{D}} \mathrm{P}$ intermedia & PS1 & 1 in 4 & 0 & 1 in 8 & 0 \\
\hline${ }^{\mathrm{b}} P$ gingivalis & W50 & 1 in 4 & 0 & 1 in 4 & 0 \\
\hline${ }^{2} P$ asaccharolytica & PS2 & 1 in 8 & 0 & 1 in 4 & 0 \\
\hline${ }^{\mathrm{a}} F$ nucleatum & PS3 & 1 in 64 & 0 & Neat & 0 \\
\hline${ }^{\mathrm{a}} F$ nucleatum & PS4 & 1 in 64 & 0 & Neat & 0 \\
\hline${ }^{\mathrm{a}} F$ necrophorum & PS5 & 1 in 8 & 0 & 1 in 8 & 0 \\
\hline
\end{tabular}

${ }^{a}$ Five embryos tested for each sample.

${ }^{b}$ Eleven embryos tested for each sample. $\lambda_{585 \mathrm{~nm}}$. Comparison between different bacterial isolates was facilitated by assuming a standard absorbance $(A=5.0$, following dilution corrections) equivalent to an undiluted/nonconcentrated sample. Standardised bacterial suspensions were then processed to produce two separate sample types for toxicity testing. These sample types were: (1) cell-free extracellular products; and (2) cell lysates (without extracellular products). Cell-free extracellular toxins were produced by removal of bacteria following centrifugation $(3000 \times g)$ for $20 \mathrm{~min}-$ utes. The supernatant (cell-free extracellular toxins) was then collected and filter-sterilised using a $0.2 \mu \mathrm{m}$ pore syringe filter (Gelman Science, Michigan, USA). The remaining bacterial cell pellets were then used to produce cell lysates. Briefly, pellets were washed three times with $5 \mathrm{ml}$ HBSS. The pellet was then freeze-thawed a minimum of five times to lyse the bacterial cells, followed by sonication for one hour to de-aggregate lysed cells. A low energy Engisonic water bath sonicator (Engis Ltd, Kent, UK), which had a maximum power of $60 \mathrm{~W}$, was used at a frequency of $50 \mathrm{Kc}$. Debris was removed by centrifugation $(3000 \times$ $g$ ) for 20 minutes and discarded and the supernatant was collected (cell lysates). The concentration of each toxin preparation was considered to be the same as that of the original bacterial suspension from which it was derived (vide supra). Toxin preparations were diluted with HBSS where necessary. An aliquot $(2 \mathrm{ml})$ of toxin preparation was autoclaved $\left(121^{\circ} \mathrm{C}, 15\right.$ lb.in ${ }^{2}, 15$ minutes) to test for the presence of endotoxin.

\section{STANDARD TOXINS}

Pure endotoxin (Escherichia coli 0.55:B5 lipopolysaccharide) was obtained from Sigma (Poole, Dorset, UK) and used at $20 \mathrm{ng} / \mathrm{ml}$ (lethal to $7.1 \%$ of embryos injected) and 80 $\mathrm{ng} / \mathrm{ml}$ (lethal to $53.8 \%$ of embryos injected). An aliquot $(2 \mathrm{ml})$ of $80 \mathrm{ng} / \mathrm{ml}$ endotoxin was autoclaved $\left(121^{\circ} \mathrm{C}, 15 \mathrm{lb}\right.$. in $^{2}, 15$ minutes) and used to test for persistence of activity. Pure nicotine was obtained from Sigma (Poole, Dorset, UK) and tested at $800 \mathrm{ng} / \mathrm{ml}$ (lethal to $22.2 \%$ of embryos injected) and $10 \mu \mathrm{g} / \mathrm{ml}$ (lethal to $55.5 \%$ of embryos injected). Endotoxin (final concentration $20 \mathrm{ng} / \mathrm{ml}$ ) and nicotine (final concentration $800 \mathrm{ng} / \mathrm{ml}$ ) were tested in combination. Endotoxin (final concentration $80 \mathrm{ng} / \mathrm{ml}$; autoclaved or nonautoclaved) and nicotine (final concentration $10 \mu \mathrm{g} / \mathrm{ml}$ ) were tested in combination, and diluted ( 1 in 2,1 in 4,1 in 8,1 in 16,1 in 32,1 in 64,1 in 128,1 in 256,1 in 512 , and 1 in 1024). The diluent used was HBSS, which was completely non-lethal.

\section{BIOASSAY}

The chick embryo bioassay was used following a published method. ${ }^{14-20}$ Toxin preparations (50 $\mu \mathrm{l})$ were injected into the chorio-allantoic vein of 11 day old chick embryos. If injection resulted in haemorrhage, the embryo was replaced. The survival of injected embryos was assessed after 18 hours' incubation at $37^{\circ} \mathrm{C}$. A 
Table 3 Synergy between nicotine (final concentration 10 $\mu \mathrm{g} / \mathrm{ml})+$ and autoclaved ${ }^{\star}$ or non-autoclaved endotoxin (final concentration $80 \mathrm{ng} / \mathrm{ml}) \neq$ serially diluted with $\mathrm{HBSS}$

\begin{tabular}{lll}
\hline Dilution & $\begin{array}{l}\text { Percentage kill with } \\
\text { non-autoclaved endotoxin }\end{array}$ & $\begin{array}{l}\text { Percentage kill with } \\
\text { autoclaved }\end{array}$ endotoxin \\
\hline Neat & 100 & 100 \\
1 in 2 & 100 & 100 \\
1 in 4 & 80 & 80 \\
1 in 8 & 80 & 90 \\
1 in 16 & 60 & 60 \\
1 in 32 & 60 & 60 \\
1 in 64 & 50 & 50 \\
1 in 128 & 50 & 40 \\
1 in 256 & 30 & 30 \\
1 in 512 & 20 & 20 \\
1 in 1024 & 0 & 10 \\
\hline
\end{tabular}

$\star 15$ minutes at $121^{\circ} \mathrm{C}, 15 \mathrm{lb} . \mathrm{in}^{2}$, lethal to $60 \%$ of embryo tested.

†Lethal to $55.5 \%$ of embryos tested.

$\ddagger$ Lethal to $53.8 \%$ of embryos tested.

Each sample was tested in 10 embryos.

minimum of five and maximum of 11 embryos were injected for samples.

PRE-SYNERGY TESTING

Cell-free extracellular toxins and cell lysates from all 10 isolates were tested in the chick embryo assay, neat and diluted ( 1 in 2,1 in 4,1 in 8,1 in 16,1 in 32 , and 1 in 64) with HBSS. Embryos were also challenged with HBSS alone as a negative control. Dilutions were chosen for all cell-free extracellular toxins and cell lysates which were completely non-lethal. Dilutions used are given in table 2 .

\section{SYNERGY TESTING}

Non-lethal concentrations of cell-free extracellular toxins (autoclaved and non-autoclaved) and cell lysates (autoclaved and nonautoclaved) from all 10 isolates were combined with nicotine at a sub-lethal concentration (final concentration $800 \mathrm{ng} / \mathrm{ml}$ ).

\section{Results}

Synergy occurred between sub-lethal concentrations of endotoxin $(20 \mathrm{ng} / \mathrm{ml})$ and nicotine $(800 \mathrm{ng} / \mathrm{ml})$, which when combined killed $60 \%$ of embryos. Synergy was also observed when endotoxin $(80 \mathrm{ng} / \mathrm{ml})$ and nicotine $(10 \mu \mathrm{g} / \mathrm{ml})$ were tested in combination over a range of dilutions. There was no significant difference in results obtained using either autoclaved or non-autoclaved endotoxin using the Fisher's Exact test (table 3).

Lethal synergy between either cell-free extracellular toxins or cell lysates of $P$ intermedia and nicotine was least likely to occur (table 4). Only the cell-free extracellular toxins of $P$ intermedia (PS1) interacted synergistically with nicotine. Lethal synergy did occur between nicotine and cell-free extracellular toxins of $P$ intermedia (PS1), $P$ gingivalis (W50), $P$ asaccharolytica (PS2), F nucleatum (PS3 and PS4), and F necrophorum (PS5). Synergy also occurred between nicotine and cell lysates of $P$ intermedia (PS1), $P$ gingivalis (W50), $P$ asaccharolytica (PS2), and $F$ necrophorum (PS5).

There was great heterogeneity between the toxicity of cell-free extracellular toxins and cell lysates of the 10 isolates (table 2). Dilutions used ranged from neat to $1.6 \%$ concentrated (1 in 64 dilution) for cell-free extracellular toxins; and from neat to $12.5 \%$ concentrated ( 1 in 8 dilution) for cell lysates. Cell-free extracellular toxins of both the $F$ nucleatum isolates (PS3 and PS4) were the most toxic, and required a 1 in 64 dilution for the synergy experiments. Cell-free extracellular toxins of $P$ intermedia MH3 and ATCC 25261 were the least toxic, and were used neat in the synergy experiments. Cell lysates of $P$ intermedia PS1 and $F$ necrophorum PS5 were the most toxic, and required a 1 in 8 dilution for the synergy experiments. Cell lysates of both $F$ nucleatum isolates (PS3 and PS4) were the least toxic, and were used neat in the synergy experiments.

The lethality of cell-free extracellular toxins and cell lysates from individual isolates were not comparable (table 2). This was most apparent with both $F$ nucleatum isolates (PS3 and PS4), where cell-free extracellular toxins required a 1 in 64 dilution in synergy experiments, and cell lysates were used undiluted. Only $P$ intermedia (MH6) and $P$ gingivalis (W50) had cell-free extracellular toxins and cell lysates of equal toxicity.

In all cases, the percentage kill observed upon combination of nicotine $(800 \mathrm{ng} / \mathrm{ml})$ and cell-free extracellular toxins or cell lysates of all 10 isolates was greater than that expected by simple addition (table 4). Statistical analysis using the $\chi^{2}$ test showed that the observed increases were not significant in all cases. Increased toxicity upon combination of cellfree extracellular toxins and nicotine (800 $\mathrm{ng} / \mathrm{ml}$ ) was significant to the $\mathrm{p}<0.05$ level for: $P$ intermedia (PS1), $P$ gingivalis (W50), $P$ asaccharolytica (PS2), F nucleatum (PS3 and PS4), and $F$ necrophorum (PS5). Cell-free extracellular toxins of $P$ gingivalis (W50), $F$ nucleatum (PS3 and PS4) and F necrophorum (PS5) also exhibited increased toxicity, which was significant to the $p<0.001$ level. Increased toxicity upon combination of cell lysates and nicotine $(800 \mathrm{ng} / \mathrm{ml})$ was significant to the $\mathrm{p}<0.05$ level for $P$ intermedia (PS1), $P$ gingivalis (W50), $P$ asaccharolytica (PS2), and $F$ necrophorum (PS5). Significance for cell lysates of $P$ intermedia (PS1) at the $\mathrm{p}<0.05$ level (table 4) was achieved because 11 embryos were tested per sample as opposed to five.

There was no significant difference in lethality in the chick embryo model for autoclaved or non-autoclaved cell-free extracellular toxins or cell lysates of all 10 putative periodontopathogens using the Fisher's Exact test (table 5).

\section{Discussion}

The combination of nicotine and cell-free extracellular toxins or cell lysates may result in a significant increase in lethality in the chick embryo model.

The putative periodontopathogens used in this study produce a range of enzymes, toxins, toxic surface associated material, and endotoxin (LPS) ${ }^{8}$ These bacterial products are capable of inducing inflammatory mediators, cytokines, and immune responses. ${ }^{25-28}$ The results show that lethal synergy occurs between nicotine and $E$ coli endotoxin (autoclaved or 
Table 4 Percentage kill of cell-free extracellular toxins and cell lysates from periodontal isolates with and without nicotine (final concentration $800 \mathrm{ng} / \mathrm{ml}$ ) $t$

\begin{tabular}{|c|c|c|c|c|c|}
\hline \multirow[b]{2}{*}{ Species } & \multirow[b]{2}{*}{ Strain } & \multicolumn{2}{|c|}{ Cell-free extracellular toxins } & \multicolumn{2}{|l|}{ Cell lysates } \\
\hline & & Without nicotine $e^{a}$ & With nicotine ${ }^{c}$ & Without nicotine $e^{a}$ & With nicotine ${ }^{c}$ \\
\hline P intermedia & MH3 & 0 & 40 & 0 & 40 \\
\hline P intermedia & MH6 & 0 & 30 & 0 & 40 \\
\hline$P$ intermedia & ATCC 25261 & 0 & 40 & 0 & 50 \\
\hline$P$ intermedia & MH15 & 0 & 50 & 0 & 40 \\
\hline$P$ intermedia & PS1 & $0^{\mathrm{b}}$ & $80^{\star d}$ & $0^{\mathrm{b}}$ & $33^{\mathrm{d}}$ \\
\hline$P$ gingivalis & W50 & $0^{\mathrm{b}}$ & $73^{\star \star \star d d}$ & $0^{\mathrm{b}}$ & $40^{\star d}$ \\
\hline$P$ asaccharolytica & PS2 & 0 & $70^{\star}$ & 0 & $80^{\star}$ \\
\hline F nucleatum & PS3 & 0 & $100^{\star \star \star \star \star}$ & 0 & 40 \\
\hline$F$ nucleatum & PS4 & 0 & $100^{\star}, \star \star \star$ & 0 & 50 \\
\hline F necrophorum & PS5 & 0 & $100^{\star} \star \star \star \star$ & 0 & $70^{\star}$ \\
\hline
\end{tabular}

* Significant to the $\mathrm{p}<0.05$ level using $\chi^{2}$ test.

$\star \star \star$ Significant to the $p<0.001$ level using $\chi^{2}$ test.

†Lethal to $22.2 \%$ of embryos tested.

${ }^{a}$ Five embryos tested for each sample except ${ }^{b}$ where 11 embryos were tested for each sample.

Ten embryos tested for each sample except ${ }^{\mathrm{d}}$ where 15 embryos were tested for each sample.

non-autoclaved); nicotine may also interact with other extracellular and cell associated toxins produced by the periodontopathogens studied. This interaction has been seen between toxins of SIDS associated Gram positive and Gram negative bacteria. ${ }^{16}$ Additionally, interaction between endotoxin of putative periodontopathogens with extracellular toxins of Gram positive bacteria may enhance toxicity further. ${ }^{14}{ }^{15}$ Autoclaving of cell-free extracellular toxins and cell lysates from all 10 putative periodontopathogens had no significant effect on lethality in the presence of nicotine in the chick embryo model. This would suggest that endotoxin was the primary toxin interacting with nicotine as proteinaceous toxins are denatured and destroyed by autoclaving.

The concentration of nicotine used in the synergy experiments $(800 \mathrm{ng} / \mathrm{ml})$ equates to 40 ng/embryo or approximately $0.57 \mu \mathrm{g} / \mathrm{kg}$ body weight (assuming a mean embryo weight of 70 g). For comparison, a $70 \mathrm{~kg}$ adult absorbs approximately $1 \mathrm{mg}$ nicotine from one cigarette $(14.2 \mu \mathrm{g} / \mathrm{kg}){ }^{16}$ Furthermore, combination of nicotine $(10 \mu \mathrm{g} / \mathrm{ml})$ and endotoxin $(80 \mathrm{ng} / \mathrm{ml})$ resulted in synergy which was highly dilutable (table 3) such that an effect was seen at a 1 in 512 dilution. This equates to a nicotine dose of $0.98 \mathrm{ng} / \mathrm{embryo}$ or $0.014 \mu \mathrm{g} / \mathrm{kg}$. Hence, the doses used in the present study are well within the physiologically relevant levels of nicotine encountered by a smoker on a $\mu \mathrm{g} / \mathrm{kg}$ body weight basis.

Cigarette smoke itself contains toxic substances such as acrolein and cyanide, the concentrations of which in one inhalation of smoke, can inhibit oral leucocyte function. ${ }^{1221}$ Nicotine transiently depresses the chemotaxis of systemic polymorphonuclear leucocytes (PMNs). ${ }^{12}$ Nicotine also upregulates neutrophil and monocyte superoxide and interleukin-1 $\beta$ production ${ }^{22}$ as well as LPS mediated monocyte secretion of prostaglandin $\mathrm{E}_{2}{ }^{23}$ Nicotine depresses both the viability and phagocytic activity of oral $\mathrm{PMNs}^{12}$ and inhibits growth and collagen and fibronectin production by gingival fibroblasts. ${ }^{24}$ The levels of systemic IgG, IgM, and oral IgA are also suppressed by nicotine and the water soluble components of cigarette smoke. ${ }^{12}$ If nicotine does potentiate bacterial toxins in progressive periodontitis, it would explain why periodontal bone loss is related to smoking rather than to specific plaque microbiology. ${ }^{431}$

Interactions, such as those illustrated in the present study, could be mediated through excess production of cytokines, which are known to play an important role in the action of Gram positive exotoxins, ${ }^{29}{ }^{30}$ Gram negative endotoxin, ${ }^{31}$ and nicotine. ${ }^{32}$ Unabated production of inflammatory cytokines such as interleukin-1 and tumour necrosis factor- $\alpha$ can cause localised tissue damage. Their amplified production through the simultaneous action of endotoxin and nicotine on tissue and on circulating leucocytes may exacerbate localised tissue damage, thereby increasing the severity of periodontal disease. Cytokines may therefore provide an underlying unifying molecular basis for action of toxins of putative periodontopathogens as well as for the synergistic interactions of endotoxin and nicotine. ${ }^{2633}$

Table 5 Percentage kill of autoclaved and non-autoclaved cell-free extracellular toxins and cell lysates from periodontal isolates

\begin{tabular}{|c|c|c|c|c|c|}
\hline \multirow[b]{2}{*}{ Species } & \multirow[b]{2}{*}{ Strain } & \multicolumn{2}{|c|}{ Cell-free extracellular toxins } & \multicolumn{2}{|l|}{ Cell lysates } \\
\hline & & Autoclaved $^{a}$ & Non-autoclaved ${ }^{a}$ & Autoclaved $^{a}$ & Non-autoclaved ${ }^{a}$ \\
\hline P intermedia & $\mathrm{MH} 3$ & 60 & 40 & 40 & 40 \\
\hline$P$ intermedia & MH6 & 50 & 30 & 40 & 40 \\
\hline P intermedia & ATCC 25261 & 50 & 40 & 40 & 50 \\
\hline$P$ intermedia & MH15 & 60 & 50 & 40 & 40 \\
\hline$P$ intermedia & PS1 & 80 & $80^{\mathrm{b}}$ & 40 & $33^{\mathrm{b}}$ \\
\hline$P$ gingivalis & W50 & 80 & $73^{b}$ & 40 & $40^{b}$ \\
\hline$P$ asaccharolytica & PS2 & 80 & 70 & 80 & 80 \\
\hline F nucleatum & PS3 & 100 & 100 & 40 & 40 \\
\hline F nucleatum & PS4 & 100 & 100 & 50 & 50 \\
\hline F necrophorum & PS5 & 100 & 100 & 90 & 70 \\
\hline
\end{tabular}

aTen embryos tested for each sample except ${ }^{b}$ where 15 embryos were tested for each sample. 
Clearly, human periodontal tissues differ from those of chick embryos so that extrapolation of data from one animal system to another should be undertaken with great caution as with all results from animal test systems. However, the present findings suggest that nicotine may enhance the potency of periodontopathic bacterial products and points the way to further research which hopefully will cast light on fundamental mechanisms underlying the role of smoking in periodontal diseases.

This work was funded by Colgate-Palmolive Ltd.

1 Scragg R, Mitchell EA, Taylor BJ, Stewart AW, Ford RPK, Thompson JMD, et al. Bed sharing, smoking and alcohol in the sudden infant death syndrome. BMF 1993;307:131218.

2 Österberg T, Mellström D. Tobacco smoking: a major risk factor for loss of teeth in three 70 -year-old cohorts. Community Dent Oral Epidemiol 1986;14:367-70.

3 Bergström J, Eliasson S. Cigarette smoking and alveolar bone height in subjects with a high standard of oral bone height in subjects with a high s

4 Bergström J, Eliasson S, Preber H. Cigarette smoking and periodontal bone loss. $\mathcal{F}$ Periodontol 1991;62:242-6.

5 Beck JD, Kock GG, Zambon JJ, Genco RJ, Tudor GE Evaluation of oral bacteria as risk indicators for periodontitis in older adults. $\mathcal{F}$ Periodontol 1992;63:93-9.

6 Johnson BD, Engel D. Acute necrotizing ulcerative gingivitis. A review of diagnosis, etiology and treatment. F Periodontol 1986;57: 141-50.

7 Stoltenberg JL, Osborn JB, Pihlstrom BL, Herzberg MC, Aeppli DM, Wolff LF, et al. Association between cigarette smoking, bacterial pathogens, and periodontal status. $\mathcal{F}$ Periodontol 1993;64:1225 30 .

8 Socransky SS, Haffajee AD. The bacterial etiology of destructive periodontal disease: current concepts. $\mathcal{F}$ Perioddestructive periodontal

9 Bergström J. Cigarette smoking as a risk factor in chronic periodontal disease. Community Dent Oral Epidemiol 1989, 17:245-7.

10 Bergström J, Linder LE. Occurence of periodontopathogens in smoker and non-smoker patients. $\mathcal{F}$ Clin Periodonto 1992;19:667-71.

11 Riviere GR, Smith KS, Tzagaroulaki E, Kay SL, Zhu X, DeRouen TA, Adams DF. Periodontal status and detection frequency of bacteria at sites of periodontal health and gingivitis. F Periodontol 1996;67:109-15.

12 Rivera-Hidalgo F. Smoking and periodontal disease. A review of the literature. $\mathcal{F}$ Periodontol 1986;57:617-24

13 Petsios A, Nakou M, Manti F. Microflora in adult periodontisis. F Periodont Res 1995;30:325-31.

14 Sayers NM, Drucker DB, Morris JA, Telford DR. Lethal synergy between toxins of staphylococci and enterobacteria: implications for sudden infant death syndrome. F Clin Pathol 1995;48:929-32.
15 Sayers NM, Drucker DB, Morris JA, Telford DR. Significance of endotoxin in lethal synergy between bacteria associated with sudden infant death syndrome. $\mathcal{f}$ Clin Pathol 1996;49:365-8.

16 Sayers NM, Drucker DB, Morris JA, Telford DR. Effect of nicotine on bacterial toxins associated with SIDS. Arch Dis Child 1995;73:549-51.

17 McKendrick N, Drucker DB, Morris JA, Barson AJ, Oppenheim BA, Crawley BA, et al. Bacterial toxins: a possible cause of cot-death. F Clin Pathol 1992;45:49-53.

18 Gomes BPFA, Drucker DB, Lilley JD. Association of specific bacteria with some endodontic symptoms and signs. Int Endod f 1994;27:291-8.

19 Drucker DB, Aluyi HS, Morris JA, Telford DR, Gibbs A. Lethal synergistic action of toxins of bacteria isolated from sudden infant death syndrome. F Clin Pathol 1992;45:799801 .

20 Eichhorn EA. A technique for the intravenous inoculation of chick embryos. Science 1940;92:243-6.

21 MacFarlane GD, Herzberg MC, Wolff LF, Hardie NA Refactory periodontitis associated with abnormal polymorphonuclear leukocyte phagocytosis and cigarette smoking. $\mathcal{f}$ Periodontol 1992;63:908-13.

22 Pabst MJ, Pabst KM, Collier JA, Coleman TC, LemonsPrince ML, Godat MS, et al. Inhibition of neutrophil and monocyte defensive functions by nicotine. 7 Periodontol 1995;66: 1047-55.

23 Payne JB, Johnson GK, Reinhardt RA, Dyer JK, Maze CA Dunning DG. Nicotine effects on $\mathrm{PGE}_{2}$ and IL-1 $\beta$ release on LPS-treated human monocytes. F Periodont Res 1996;31:99-104.

24 Tipton DA, Dabbous MK. Effects of nicotine on proliferation and extracellular matrix production of human gingival fibroblasts in vitro. $\mathcal{F}$ Periodontol 1995;66:1056-64.

25 Meghii S, Henderson B, Kirby A, Newman HN, Wilson M. Serum antibody response to surface-associated-material from periodontopathogenic bacteria. FEMS Immunol Med Micro 1995;10:101-8.

26 Agarwal S, Piesco NP, Johns LP, Riccelli AE. Differential Expression of IL- $1 \beta$, TNF- $\beta$, IL-6, and IL- 8 in human monocytes in response to lipopolysaccharides from different microbes. F Dent Res 1995;74:1057-65.

27 Dongari-Bagtzoglou AI, Ebersole JL. Production of inflammatory mediators and cytokines by human gingival fibroblasts following bacterial challenge. $f$ Periodont Res 1996;31:90-8.

28 Lindermann RA, Kjeldsen M, Cabret M. Effect of whole oral bacteria and extracted lipopolysaccharides on peripheral blood leukocyte interleukin-2 receptor expression. $f$ Periodont Res 1995;30:264-71.

29 Marrak P, Kappler J. The staphylococcal enterotoxins and their relatives. Science 1990;248:705-11.

30 Fujikawa $H$, Igarashi $H$, Usami $H$, Tanaka $S$, Tamura $H$ Clearance of endotoxin from blood of rabbits injected with staphylococcal toxic syndrome toxins. Infect Immun 1986; 52:134-7.

31 Stone RL, Schlievert PM. Evidence for the involvement of endotoxin in toxic shock syndrome. $\mathcal{F}$ Infect Dis 1987;134: 682-9.

32 Lemanske RF. Mechanism of airway inflammation. Chest 1992;101:372S-7S

33 Haber J, Kent RL. Cigarette smoking in a periodontal practice. F Periodontol 1992;63:100-6. 